\title{
Research on the Location Choice of Chinese Enterprises' Overseas Investment under the Motivation for Seeking natural resources in Host Country
}

\author{
Yuting Wang ${ }^{1, *}$ \\ ${ }^{1}$ School of Economics and Management, Beijing Jiaotong University, Beijing, 100044, China
}

\begin{abstract}
Since the "Belt and Road" initiative was put forward in 2013, China's overseas investment has achieved rapid development. As a country with high energy consumption, China's demand for the host country's natural resources such as iron ore and fuel is increasing. The impact of motivation for seeking natural resources on the location choice of Chinese enterprises' overseas investment has also received extensive attention. This paper selects the overseas investment records of Chinese companies in 40 countries from 2007 to 2017 as a sample. And this paper uses the conditional logit model to explore the impact of the host country's natural resources on the location choice of Chinese enterprises' overseas investment with different ownerships under the "Belt and Road" initiative. The study found that the natural resource endowment of the host country has a significant positive impact on the location choice of Chinese enterprises' overseas investment. And it has a stronger promotion effect on the overseas investment of Chinese state-owned enterprises. The "Belt and Road" initiative has significantly improved the role of the host country's natural resource endowment in the location choice of China's non-state-owned enterprises' overseas investment.
\end{abstract}

\section{Introduction}

Since the "Belt and Road" initiative was put forward in 2013, China's overseas investment has achieved rapid development. In 2018, China's outward foreign direct investment reached 143.04 billion U.S. dollars. And China became the second largest outward foreign direct investment country in the world. China invests in 188 countries and regions around the world. At the same time, China is a country with high energy consumption. And its demand for resources such as fuel oil and iron ore is rising. Therefore, the impact of the natural resources of the host country represented by iron ore and fuel oil on the location choice of Chinese enterprises' overseas investment has also received widespread attention. Studies have found that the richer the host country's natural resources such as iron ore and fuel oil are, the more favourable it is to attract Chinese investment ${ }^{[1]}$. Other Studies have also pointed out that the abundance of natural resources in the host country has a significant impact on non-trade overseas investment but not on trade overseas investment [2]. When considering the heterogeneity of countries and enterprises, it is found that China does not have significant resource-seeking motives for investment in developing countries ${ }^{[3]}$. There is a significant positive correlation between the overseas investment of Chinese state-owned enterprises and the natural resource endowment of the host country ${ }^{[4]}$.The above research shows that Chinese enterprises' overseas investment has a significant resource seeking motivation. But the current research does not consider the impact of the host country's natural resources on the overseas investment location choices of Chinese enterprises with different ownerships under the "Belt and Road" initiative. It is difficult to learn the influence of policy factors. Based on this, this article aims to explore the impact of the natural resources of the host country on the investment location choices of Chinese enterprises with different ownerships under the "Belt and Road" initiative and to provide references to enhance enterprises' overseas investment under the "Belt and Road" initiative.

\section{Theoretical analysis and assumptions}

China is a country with high energy consumption. Its demand for natural resources such as fuel oil is much larger than its domestic production. In the meantime, the demand for minerals is also increasing year by year. China's foreign dependence on natural resources such as fuel oil and minerals is increasing. Over the past decade or so, energy projects have been the hottest industry for China's overseas investment and construction. In 2018, the proportion of overseas investment and mergers and acquisitions in the mining industry, which is composed mainly of energy resource industries such as oil and gas extraction, non-ferrous metal extraction and ferrous metal extraction reached $12.4 \%$. It indicates that Chinese companies' overseas investment does have significant

\footnotetext{
Corresponding author: 18120550@bjtu.edu.cn
} 
natural resource seeking motivation. At the same time, compared with non-state-owned enterprises, state-owned enterprises have relatively strong financial strength and receive greater government support. When making decisions about overseas investment, they not only aim at maximizing corporate value ${ }^{[5]}$, but also meet the country's strategic needs. Energy resources are a key factor in national development. In order to meet the national energy strategic needs, the overseas investment of state-owned enterprises has a stronger motivation to seek natural resources. Based on this, hypothesis 1 of this article is proposed.

Hypothesis 1: The natural resources of the host country play a significant role in promoting the location choice of overseas investment of Chinese enterprises. And it has a stronger role in promoting the overseas investment of state-owned enterprises.

\section{Variable selection and model setting}

\subsection{Variable and sample selection}

This article studies the location choice of enterprises' overseas investment. The explained variable is a binary choice variable. If enterprise $i$ makes overseas investment in country $j$ in year $t$, the explained variable takes the value 1 , otherwise it takes the value 0 . And the variable is represented by CMA. The explanatory variable is the natural resource endowment of the host country, which represents its abundance of natural resources. In order to obtain certain natural resources, enterprises tend to invest in countries with relatively abundant natural resources ${ }^{[1]}$. A country's natural resource endowment can be expressed by the proportion of iron ore, metal and fuel oil exports in the country's total exports ${ }^{[6]}$.

In addition to the host country's natural resource endowment, there are many other variables affecting China's overseas investment. The following control variables are introduced: (1) intellectual property rights protection (IPRP). There are many methods for measuring the level of intellectual property protection in host countries. This article selects the intellectual property index measured by the questionnaire method, which can more accurately and comprehensively reflect the protection of intellectual property in various countries. The data comes from the Global Competitiveness Report. (2) strategic assets (SA). The proportion of a country's exports of high-tech products in its total exports can represent the ownership of strategic assets in a country. The data comes from the World Bank. (3) geographic distance (DIS): The geographic distance between the two countries can be expressed as the logarithm of the product of the population-weighted average distance and the fuel price of the year. The population-weighted average distance data comes from the CEPII database. And the fuel price is the average of the London North Sea Brent and US WTI spot oil prices. (4) Host country market size (GDP): Chinese enterprise investment has significant market- oriented characteristics. The gross domestic product of a country can reflect the market size of a country. The data comes from the World Bank. (5) Trade dependence (LTRADE): The degree of a country's trade dependence on China can be measured by the proportion of its total import and export trade with China in its total international trade. The data comes from the UN Comtrade database. (6) Host country political system (GOV). The political system is expressed through the World Bank's Worldwide Governance Indicator, which specifically includes six indicators. The political system is expressed by the equal weighted average of the six indicator scores. (7) The cultural distance (CD): This paper selects the Hofstede index to measure the cultural distance between China and the host country. This index quantifies cultural characteristics from six dimensions of power distance, individualism, masculinity, uncertainty avoidance, long-term orientation, and tolerance. This paper draws on the distance index formula proposed by Kogut and Singh [7] to construct cultural distance variables, and the calculation method is shown in formula (1).

$$
C D_{i}=\sum_{j=1}^{n}\left[\left(D_{i j}-D_{c j}\right)^{2} / V_{j}\right] / n
$$

In formula (1), $C D_{i}$ represents the cultural distance between China and the host country $i, j$ represents the sub-indicator, $D_{i j}$ represents the cultural feature score of country $i$ in the $j$ dimension, and $\mathrm{D}_{c j}$ represents the cultural feature score of China in the $j$ dimension. $V_{j}$ represents the variance of the $j$ dimension. Since the published cultural feature data of various countries have different dimensions, $\mathrm{n}$ represents the number of dimensions in each country.

This article uses the "China Global Investment Tracking" database (CGIT) launched by the American Heritage Foundation and the American Enterprise Institute to obtain the details of the overseas investment of Chinese enterprises. The scope of the sample selection is enterprises' overseas investment records from 20072018. Due to the lack of variable data in some countries, it was deleted from the sample. Finally, the overseas investment records of 40 countries $^{\text {a }}$ with complete data from 2007 to 2018 were selected as the sample.

\subsection{Model setting}

This paper selects the conditional logit model for empirical analysis, which is widely used in the location choice research of enterprises' overseas investment ${ }^{[1]}$. Under this model, the characteristics of the industry, the year, and the country where the investor company is located are determined for a particular transaction and

\footnotetext{
a 40 countries: Chile, Canada, England, Ecuador, Australia, France, Russia, Indonesia, Japan, Colombia, Egypt, South Africa, Netherlands, Singapore, Pakistan, America, Peru, Germany, Mexico, Belgium, Italy, Norway, Turkey, Greece, Switherland, Thailand, Spain, Bulgaria, Brazil, Hungary, Malaysia, Argentina, Sweden, South Korea, Israel, Portugal, Poland, New Zealand, The Czech Republic, Denmark.
} 
will not change. Only the characteristics of the host country have an impact on the choice of enterprises' investment location. Therefore, this is a program selection problem under the conditions of a specific enterprise. The investment return of the enterprise in country $j$ in program $i$ is shown in equation (2).

$$
R_{i j}=\beta_{i j} X_{j}+\varepsilon_{i j}
$$

In formula (2), $R_{i j}$ is the expected return. $X_{j}$ is the observable feature of country $j . \beta_{i j}$ is the parameter vector to be estimated. And $\varepsilon_{i j}$ is the random error term. The goal of enterprise investment is to maximize profits. Therefore, the enterprise must choose the solution that maximizes its return on investment. This means that if the expected return $R_{i j}$ of the enterprise in country $j$ is greater than the return $R_{i k}$ of any other alternative country $k$, the company will choose country $j$. If the random error terms are independent and have the same extreme value, the probability of a company to invest in country $j$ is shown in equation (3).

$$
P_{i j}=\frac{\exp \left(\beta X_{j}\right)}{\sum_{1}^{k} \exp \left(\beta X_{k}\right)}
$$

In formula (3), $k$ is the number of other countries or regions that can be selected. The maximum likelihood method is used to estimate $\beta$. In this study, $k$ is 39 .

This paper uses the conditional logit model to examine the impact of the host country's natural resource endowment on the location choice of Chinese enterprises' overseas investment. The specific measurement model is shown in equation (4).

$$
\begin{aligned}
C M A_{i j t}= & \beta_{0}+\beta_{1} R A W_{j t}+\beta_{2} I P R P_{j t}+\beta_{3} S A_{j t}+\beta_{4} l n D I S_{j t}+\beta_{5} \operatorname{lnGDP_{jt}}+ \\
& \beta_{6} L T R A D E_{j t}+\beta_{7} G O V_{j t}+\beta_{8} C D_{j t}+\varepsilon_{i j t}
\end{aligned}
$$

In formula (4), $i$ represents the enterprise, $t$ represents the year, $j$ represents the country, $\beta_{0}$ is the intercept term, $\varepsilon_{i j t}$ is the error term, and $\beta_{i}$ is the corresponding coefficient.

\section{Empirical results and analysis}

\subsection{The impact of the host country's natural resources on the location choice of enterprises' overseas investment}

This article draws on the practice of Wang et al ${ }^{[6]}$. This study uses the conditional logit model to examine the impact of the host country's natural resource endowment on the location of Chinese enterprises' overseas investment. First, it examines the impact of the host country's natural resource endowment on the location of overseas investment of enterprises under the full sample. In order to further explore the effect of the host country's natural resource endowment on enterprises of different ownership, the sample is divided into state-owned enterprises and non-state-owned enterprises according to

\begin{tabular}{|c|c|c|c|}
\hline Variables & $\begin{array}{c}\text { Full } \\
\text { sample }\end{array}$ & $\begin{array}{l}\text { state-owned } \\
\text { enterprises }\end{array}$ & $\begin{array}{l}\text { non-state-owned } \\
\text { enterprises }\end{array}$ \\
\hline RAW & $\begin{array}{l}1.833^{* * *} \\
(9.020)\end{array}$ & $\begin{array}{c}2.114^{* * *} \\
(7.700)\end{array}$ & $\begin{array}{l}1.362^{* * *} \\
(4.380)\end{array}$ \\
\hline IPRP & $\begin{array}{l}0.368^{* * *} \\
(4.440)\end{array}$ & $\begin{array}{l}0.458^{* * *} \\
(4.310)\end{array}$ & $\begin{array}{c}0.251^{*} \\
(1.940)\end{array}$ \\
\hline SA & $\begin{array}{c}2.180^{* * *} \\
(5.460)\end{array}$ & $\begin{array}{l}1.762^{* * *} \\
(3.150)\end{array}$ & $\begin{array}{l}2.774^{* * *} \\
(4.820)\end{array}$ \\
\hline Ln DIS & $\begin{array}{l}0.574^{* * *} \\
(8.630)\end{array}$ & $\begin{array}{l}0.653^{* * *} \\
(6.860)\end{array}$ & $\begin{array}{l}0.507^{* * *} \\
(5.360)\end{array}$ \\
\hline Ln GDP & $\begin{array}{l}0.670^{* * *} \\
(23.510)\end{array}$ & $\begin{array}{l}0.594^{* * *} \\
(14.670)\end{array}$ & $\begin{array}{l}0.724^{* * *} \\
(17.880)\end{array}$ \\
\hline LTRADE & $\begin{array}{l}3.863^{* * *} \\
(6.990)\end{array}$ & $\begin{array}{c}4.658^{* * *} \\
(5.840)\end{array}$ & $\begin{array}{l}3.562^{* * *} \\
(4.470)\end{array}$ \\
\hline GOV & $\begin{array}{c}-0.072 \\
(-0.720)\end{array}$ & $\begin{array}{l}-0.285^{* *} \\
(-2.130)\end{array}$ & $\begin{array}{c}0.188 \\
(1.250)\end{array}$ \\
\hline $\mathrm{CD}$ & $\begin{array}{c}-0.184^{* * *} \\
(-4.680)\end{array}$ & $\begin{array}{c}-0.240^{* * *} \\
(-4.290)\end{array}$ & $\begin{array}{l}-0.116^{* *} \\
(-2.090)\end{array}$ \\
\hline $\begin{array}{l}\text { Number } \\
\text { of obs }\end{array}$ & 33638 & 15089 & 18549 \\
\hline $\begin{array}{c}\text { Pseudo- } \\
\mathrm{R}^{2}\end{array}$ & 0.162 & 0.135 & 0.200 \\
\hline $\begin{array}{c}\text { Log } \\
\text { likelihood }\end{array}$ & -3188.562 & -1554.169 & -1605.963 \\
\hline LR chi2 & 1232.020 & 485.740 & 803.140 \\
\hline
\end{tabular}
the enterprise ownership. The specific results are shown in Table 1.
Table 1. Benchmark model estimation results

Note: The $\mathrm{Z}$ value is in brackets. ${ }^{* * *},{ }^{* *}$, * are significant at the significance level of $1 \%, 5 \%$, and $10 \%$ respectively.

It can be seen from Table 1 that whether it is a stateowned enterprise or a non-state-owned enterprise, the variable's coefficient of natural resource endowment of the host country is significantly positive at the level of $1 \%$. It indicates that both state-owned and non-stateowned enterprises have natural resource seeking motivation. And the corresponding coefficient value of state-owned enterprises is significantly larger than that of non-state-owned enterprises, indicating that compared with non-state-owned enterprises, state-owned enterprises have stronger motivation to seek natural resources. Energy is one of the three elements that determine the lifeline of the country's economy. In order to ensure the development of the country's economy and meet the country's strategic needs, state-owned enterprises have stronger incentives to seek natural resources. Hypothesis 1 is verified.

\subsection{Further analysis}

As an important policy, the "Belt and Road" initiative has strengthened the facility connectivity, policy communication, and financial connectivity between China and other countries, especially countries along "the Belt and Road". Will the impact of the host country's natural resource endowment on the location choice of enterprises' investment be affected by the 
"Belt and Road" initiative? Based on this, this article uses 2013 as the boundary and divides the sample into two samples before and after the "Belt and Road" initiative was proposed. Then this study explores the impact of natural resource endowments on the investment location choices of Chinese enterprises with different ownerships before and after the "Belt and Road" policy is proposed. The regression results are shown in Table 2.

Table 2 Model estimation results after considering the "Belt and Road" initiative

\begin{tabular}{|c|c|c|c|c|}
\hline Variables & $\begin{array}{c}\text { state- } \\
\text { owned } \\
\text { enterprise } \\
\text { s\& } \\
\text { Year<= } \\
2013\end{array}$ & $\begin{array}{c}\text { state- } \\
\text { owned } \\
\text { enterprise } \\
\text { s\& } \\
\text { Year> } \\
2013\end{array}$ & $\begin{array}{c}\text { non- } \\
\text { state- } \\
\text { owned } \\
\text { enterpris } \\
\text { es\& } \\
\text { Year<= } \\
2013\end{array}$ & $\begin{array}{c}\text { non- } \\
\text { state- } \\
\text { owned } \\
\text { enterpris } \\
\text { es\& } \\
\text { Year> } \\
2013\end{array}$ \\
\hline RAW & $\begin{array}{c}2.547^{* * *} \\
(6.770)\end{array}$ & $\begin{array}{c}1.288^{* * *} \\
(2.950)\end{array}$ & $\begin{array}{c}0.283 \\
(0.500)\end{array}$ & $\begin{array}{l}1.610^{* * *} \\
(4.210)\end{array}$ \\
\hline IPRP & $\begin{array}{c}0.560^{* * *} \\
(4.240)\end{array}$ & $\begin{array}{l}0.506^{*} \\
(2.850)\end{array}$ & $\begin{array}{c}0.708^{* * *} \\
(3.480)\end{array}$ & $\begin{array}{c}0.124 \\
(0.740)\end{array}$ \\
\hline SA & $\begin{array}{l}1.488^{*} \\
(1.730)\end{array}$ & $\begin{array}{c}1.952^{* * *} \\
(2.630)\end{array}$ & $\begin{array}{c}1.539 \\
(1.330)\end{array}$ & $\begin{array}{c}3.151^{* * *} \\
(4.630)\end{array}$ \\
\hline Ln DIS & $\begin{array}{c}0.826^{* * *} \\
(5.790)\end{array}$ & $\begin{array}{c}0.566^{* * *} \\
(4.340)\end{array}$ & $\begin{array}{l}0.470^{* *} \\
(2.430)\end{array}$ & $\begin{array}{c}0.558^{* * *} \\
(5.070)\end{array}$ \\
\hline Ln GDP & $\begin{array}{c}0.586^{* * *} \\
(10.000)\end{array}$ & $\begin{array}{l}0.580^{* * *} \\
(10.090)\end{array}$ & $\begin{array}{l}0.618^{* * *} \\
(7.710)\end{array}$ & $\begin{array}{c}0.759^{* * *} \\
(15.920)\end{array}$ \\
\hline LTRADE & $\begin{array}{l}7.280^{* * *} \\
(5.810)\end{array}$ & $\begin{array}{c}3.889^{* * *} \\
(3.450)\end{array}$ & $\begin{array}{c}6.701^{* * *} \\
(3.520)\end{array}$ & $\begin{array}{c}3.094^{* * *} \\
(3.440)\end{array}$ \\
\hline GOV & $\begin{array}{l}-0.502^{* *} \\
(-2.660)\end{array}$ & $\begin{array}{c}-0.280 \\
(-1.420)\end{array}$ & $\begin{array}{c}-0.887^{* * *} \\
(-3.060)\end{array}$ & $\begin{array}{l}0.471^{* *} \\
(2.570)\end{array}$ \\
\hline $\mathrm{CD}$ & $\begin{array}{l}-0.187^{* *} \\
(-2.270)\end{array}$ & $\begin{array}{c}-0.264^{* * *} \\
(-3.460)\end{array}$ & $\begin{array}{c}0.101 \\
(0.900)\end{array}$ & $\begin{array}{c}-0.167^{* *} \\
(- \\
2.560) \\
\end{array}$ \\
\hline $\begin{array}{c}\text { Number } \\
\text { of obs }\end{array}$ & 7369 & 7720 & 4469 & 14080 \\
\hline $\begin{array}{c}\text { Pseudo- } \\
\mathrm{R}^{2}\end{array}$ & 0.161 & 0.129 & 0.171 & 0.217 \\
\hline $\begin{array}{c}\text { Log } \\
\text { likelihood }\end{array}$ & -741.614 & -795.607 & -378.681 & $\begin{array}{c}- \\
1213.85 \\
3 \\
\end{array}$ \\
\hline LR chi2 & 284.140 & 235.490 & 155.790 & 674.210 \\
\hline
\end{tabular}

Note: The $\mathrm{Z}$ value is in brackets. ${ }^{* * *},{ }^{* *},{ }^{*}$ are significant at the significance level of $1 \%, 5 \%$, and $10 \%$ respectively.

From the results in Table 2, it can be seen that before and after the "Belt and Road" initiative was put forward, the coefficient of natural resource endowment in the host country under the sample of state-owned enterprises was significantly positive, indicating that before and after the policy was put forward, Chinese state-owned enterprises have significant natural resource seeking motivations. However, for non-state-owned enterprises, before the "Belt and Road" initiative was put forward, the natural resource endowment of the host country did not have a significant impact on them. After the "Belt and Road" initiative was put forward, the host country's natural resources showed a significant promotion effect. Compared with state-owned enterprises in China, most of non-state-owned enterprises have relatively weak financial strength. The payback period of natural resource investment capital is long, which is difficult for non-state-owned enterprises to afford. After the "Belt and Road" initiative was put forward, the government actively introduced corresponding policies to encourage companies to invest in energy and infrastructure in countries along "the belt and road". Non-state-owned enterprises are more convenient in financing and receive more government support, which enhances the motivation of non-state-owned enterprises to seek natural resources. Therefore, after the "Belt and Road" initiative was put forward, the natural resource endowment of the host country can significantly promote non-state-owned enterprises' overseas investment.

\section{Conclusion}

This paper uses the conditional logit model to explore the impact of the host country's natural resource endowment on the investment location choices of Chinese enterprises with different ownerships. And it considers the role of the "Belt and Road" initiative. The conclusion is as follows: Chinese enterprises have significant natural resource seeking motivations for overseas investment. And state-owned Enterprises have stronger motivations for seeking natural resources. The proposal of "the Belt and Road" initiative has significantly enhanced the motivations of non-stateowned enterprises in seeking natural resources.

\section{References}

1. P.J. Buckley, L.J. Clegg., A.R. Cross., et al. The Determinants of Chinese Outward Foreign Direction Investment[J]. Journal of International Business Studies, 38,4: 499-518(2007).

2. B.P. Jiang, S.X. Dai. Study on the difference of location choice between two types of outward foreign direct investment[J]. Journal of commercial economics, 1: 145-147(2019).

3. Y. Z. Wang, Q.F. Zhao. Risk Preference, Investment Motives and China's Outward Direct Investment: Panel Data Analysis[J]. Chinese Review of Financial Studies, 8,4:1-17(2016).

4. L.F. Song, H. W. Risks of Host Countries, Natural Resources and State-Owned Firms' ODI[J]. Journal of international trade, 3: 149-162(2018).

5. G.H. Jiang. Outward Direct Investment and Chinese Firm's Heterogeneity: Evidence from the Chinese Fi $\mathrm{rms}[\mathrm{J}]$. Journal of financial research,12:81-96(2015).

6. Y. Q. Wang, J.L. Du. K. Wang. The determinants of location choices of China's ODI: Institutions, Taxations, Resources[J]. Economic research journal,49,12: 126-142(2014). 
7. B. Kogut, H. Singh. The effect of national culture on the choice of entry mode[J]. Journal of international business studies, 19,3: 411-432(1988). 